\title{
Glasgow University
}

\section{Tim Jarvis}

\section{'Pleasure balks, bliss appears' or 'The apparatus shines like a blade': Towards a theory of a progressive reading praxis in Creative Writing pedagogy}

\author{
Abstract \\ This article argues that a reformation of Creative Writing's reading praxis is \\ required if it is to develop its unique potential as a field of intellectual enquiry. \\ Roland Barthes, in his essay 'On Reading', identifies three types of reading \\ pleasure. The third of these modes is that of 'Writing', in which 'reading is a \\ conductor of the Desire to write'. Of this mode, Barthes writes: \\ Is this pleasure of production an elitist pleasure, reserved only \\ to potential writers? In our society, a society of consumption \\ and not production, a society of reading ... and not a society of \\ writing ... everything is done to block the answer ... my \\ profound and constant conviction is that it will never be \\ possible to liberate reading if, in the same impulse, we do not \\ liberate writing. (Barthes 1989: 41)
}

It is the contention of the author of this article that the teaching of the 'reading as a writer' method in Creative Writing classrooms gives rise to a situation the inverse of that Barthes describes; it makes Creative Writing into a 'society of writing' in which reading is trammelled. The article explores and critiques the 'reading as a writer' technique, examines various progressive models of Creative Writing reading praxis, and proposes a radical 'writerly reading' praxis suggested by concepts from the work of Michel de Certeau. Keywords: Pedagogy, 'reading as a writer', experimental fiction

\section{Reading is a conductor of the desire to write}

Roland Barthes, in his essay 'On Reading', identifies three types of reading pleasure; three modes in which texts can be read. The first, which he terms a 'kind of metaphoric or poetic reading', is 'fetishist': pleasure taken purely in words, in the arrangement of words, a pleasure which does not require semantic structure (Barthes 1989: 40). The second is the exact contrary of the first:

the reader is drawn onward through the book's length by a force always more or less disguised, belonging to the order of suspense: the book is gradually abolished, and it is in this impatient, impassioned erosion that the delectation lies.

(Barthes 1989: 40) 
This is a reading structured by social and ideological codes of meaning, codes embedded in novelistic conventions such as narrative and character. The third mode is that of 'Writing': in this mode, 'reading is a conductor of the Desire to write' (1989: 40). This is not a desire to emulate, 'to write like the author we enjoy reading', but a desire for 'the desire the author had for the reader when he was writing', for 'the love-me which is in all writing' (1989: 40-41). Of this mode, this pleasure of reading, Barthes writes:

In this perspective ... the chain of desire begins to unroll, each reading being worth the writing it engenders, to infinity. Is this pleasure of production an elitist pleasure, reserved only to potential writers? In our society, a society of consumption and not production, a society of reading ... and not a society of writing ... everything is done to block the answer ... my profound and constant conviction is that it will never be possible to liberate reading if, in the same impulse, we do not liberate writing. (Barthes 1989: 41)

I would contend that the current centrality of the method of 'reading as a writer' to Creative Writing pedagogy gives rise to an issue that is the inverse of that which Barthes describes; 'reading as a writer' turns Creative Writing in the Academy into a society of writing in which reading is trammelled, its praxis limited to certain prescribed modes. The only way to liberate writing is to first liberate reading. I believe this is crucial if Creative Writing is to develop its unique potential as a field of intellectual enquiry. Creative Writing could provide a way to erode disciplinary boundaries - as David Morley asserts in The Cambridge Introduction to Creative Writing, 'creative writing is a discipline that slides and slices across knowledge, thereby cutting across conformity' (Morley 2007: 254). This could provide the Academy with a more flexible set of instruments with which to interrogate a rapidly changing world. Creative Writing could also provide a space for the production of experimental fiction. Experimental fiction adopts a transgressive, subversive stance towards literary conventions and, therefore, destabilises orthodox ways of perceiving the world. It promotes flux and avoids stagnation. This kind of writing should be fostered in Creative Writing departments for two reasons. First, work in the Academy should advance thought, should provoke new ways of seeing the world, which is why originality is a key criterion of achievement built into university rubrics at all levels. Second, in an era in which the literary marketplace is under great economic pressure, and publishers are increasingly loath to publish experimental work, the Academy could provide a space for the perpetuation of this tradition.

\section{'Reading as a writer'}

One of the key pedagogical methods of Creative Writing, from its outset, has been to promote reading as a means by which student writers can enhance their craft - to teach students the skill of 'reading as a writer'. Encouraging aspiring writers to read is important. First, and most obviously, because it is from literary tradition that writers learn how to situate themselves in relation to other writers, generic conventions, and traditions, and also to gain ideas for technical approaches and subjects for their fiction. Second, reading fiction is part of a discipline of attentiveness, a reading of the world, that all writers must learn. Moreover, it is crucial Creative Writing in the Academy promote a practice of reading fiction, because it should, as other disciplines do, function on an essentially collaborative premise, where new researchers engage with, build on, 
and extend work done by their precursors, and in paradigm shifts, overturn these precursors.

But what is 'reading as a writer', and how is it seen to differ from 'reading as a reader'? A representative recent chapter on the practice from a Creative Writing workbook, Mike Bunn's 'How to Read Like a Writer' (Bunn 2011), delineates the features of the methodology. It is a close reading strategy that sees reading and writing as separate activities, reading essentially the theory of Creative Writing, writing the praxis. It involves:

Questioning why the author made certain decisions.

Considering what techniques could have made the text better. Deciding how to include the best attributes of what you read in your own writing. (Bunn 2011: 85)

If the technique acknowledges that, because acts of writing are inevitably informed by ideological context, texts are ravels of cultural codes, it does so only in a superficial way, which is limited to a politics of literary influence. For example, James Friel, in his chapter on the technique in The Writer's Workbook, writes:

When you write, you are involving yourself in an enormous conversation with everyone else who has done likewise: you learn from them, correct in your own work what you dislike in the work of others, pay tribute to work you admire, establish yourself in a tradition. (Friel 2004: 13)

In his book Creative Writing and the New Humanities (2005), Paul Dawson provides an analysis of the source and development of the practice of 'reading as a writer'. He traces its origins to writers' guides that predate, by some time, Creative Writing as a subject of study in Higher Education. Its nascency he finds in Walter Besant's advice to the aspirant writer in his essay, 'The Art of Fiction' (1884), to 'with the greatest care and attention analyze and examine the construction of certain works ... so as to discover for himself how the author built up the novel, and from what original germ or conception it sprang' (Besant 1902: 69-70). Dawson then traces the development of the practice through Dorothea Brande's bestselling Becoming a Writer (1934), to its conceptualisation as part of the methodology of the burgeoning academic discipline of Creative Writing in Allen Tate's article, 'We Read as Writers' (1940). In this article Tate, according to Dawson, 'describes this reading practice by establishing an analogy with architecture; one can trace the historical origins of the architectural style of various buildings, or one can study how the building was actually constructed' (Dawson 2005: 77). The inference is that critical analysis is not within the purview of the creative writer, who should concern him- or herself only with the how of producing textual effects. This concern with structure determines, in Dawson's view, the dominant pedagogical mode of the Creative Writing workshop. This separation of the practices of the creative writer from that of the critic, through a focus on this particular reading praxis, continues in a key early work of Creative Writing pedagogy, RV Cassill's Writing Fiction (1962). Cassill distinguishes the reading practice of a writer from those of an ordinary reader or a critic. It consists of noting 'how the story, its language, and all its parts have been joined together' - as a kind of reconstruction of the creative process (Cassill 1975: 6).

\section{The problem with the 'reading as a writer' praxis}


The establishment of the praxis of 'reading as a writer', a reading practice that supposedly has a distinct motivation (that of learning how to construct a work of fiction) and calls upon a different kind of expertise (the writer's understanding of the act of composition) can be seen as part of a more general effort on the part of Creative Writing pedagogues to establish a disciplinary identity for their subject, to distinguish it from Literary Criticism. The literary scholar, it is claimed, reads a static, complete product, while the creative writer engages with a process. That this distinction should have become increasingly difficult to maintain as critical practice shifted in the late 1960s towards more motile kinds of analysis, is not acknowledged by orthodox Creative Writing pedagogy - as late as 1989, David Jauss, in his essay, 'Articles of Faith' can affirm: 'A scholar reads the product; a writer, the process' (quoted in Dawson 2005: 95). In truth, claims that 'reading as a writer' is a uniquely dynamic praxis are spurious; it can easily be seen there is little to differentiate 'reading as a writer' from the practice of the formalist or structuralist critic-modes of reading texts that are arguably regressive.

Since 'reading as a writer' articulates a view of the work of a writer as structured by a binary opposition, reading / writing, in which reading is theory, and writing, praxis, critical theory as theory is effectively excluded from the Creative Writing classroom. The 'reading as a writer' methodology also ignores the fact that all theories are simultaneously praxes. Moreover, as a formalist technique, 'reading as a writer' has the effect of suppressing the historical, sociopolitical, ideological, and affective dimensions of literature. As Nicole Cooley notes, other, more reader-focussed strategies are required to acknowledge 'that reading is a multifaceted, historically mutable enterprise' (Cooley 2003: 103). A further problem lies in the way 'reading as a writer' affects the act of composition. It is not solely a reading methodology; it impacts on writing. Students are encouraged to pursue a 'reading as a writer' in writing, a kind of editorial process, which involves interrogating the various choices made in the act of writing in a like manner to that they are enjoined to employ when reading published texts. This leads to an emphasis on a particular model of writing, one that aspires towards creative unity. Composition becomes an act of imposing coherence upon the ill-formed matter of writing - students' figments and experiences - through the exercise of the faculty of reading. Cassill writes that the writer 'has to ... impose unity on raw material that has none' (Cassill 1975: 143). This view of the value of 'reading as a writer' to composition stems from what might be called a semantic bias: 'The passionate wish to make experience yield a particular meaning is the heart of the creative act, the initial selection from which subsequent choices flow with an increasingly rational justification' (Cassill 1975: 144). This notion is also advanced by other early texts in the discourse, for example Cleanth Brooks and Robert Penn Warren's Understanding Fiction (1959).

In Kenneth Patchen's novel, The Journal of Albion Moonlight (1941), the narrator muses on the question of imposing structure on the chaotic creative outpouring: 'as an artist I could have wished that there had been more structure and design to it - as a man, that there had been less of the kind there was' (Patchen 1961: 305). Emphasising structural concord to too great an extent, or by too slavishly following existing conventions (of course many structural conceits, particularly innovative ones can be very potent) can diminish a work's polysemy. Polysemic literature gives rise to a host of conflicting interpretations in the mind of readers, it works heuristically, forcing readers to think independently about ideas and concepts for themselves, avoiding dogma and didacticism. Therefore, as 'reading as a writer' while reading elides the historical, sociopolitical, ideological, and affective dimensions of the text of another, 'reading as a writer' while writing, though it cannot prevent these elements from appearing in the fiction, may prevent them from being presented 
in interesting and complex ways (it is always possible to read a univocal text against the grain, to unearth its hidden meanings, but that does not invalidate the value of polysemic work).

\section{Reforming 'reading as a writer'}

A number of recent discussions in the theory of Creative Writing pedagogy have specifically addressed the 'reading as a writer' problematic. Andrew Melrose, in his paper, 'Reading and Righting' (2007), argues for the need to rethink 'reading as a writer', to move beyond the close reading model by bringing 'critical theory' into the discussion. He advocates uniting the practices of reading and writing under the skill of 'thinking', a strategy he hopes will address the gap between Creative Writing and Literary Studies: 'it should ... be remembered that while writers make better critics, so too do better readers make better writers, so the separation in the disciplines is paper thin' (Melrose 2007: 115). Dawson advocates a shift, based on an incorporation of Bakhtinian dialogism into Creative Writing pedagogy, 'from a formalist poetics to a sociological poetics' (Dawson 2005: 208). He argues that only by 'exploring the political and discursive effects of their literary products and accepting responsibility for them', can Creative Writing establish its intellectual value within the Academy (Dawson 2005: 214). However, while both of these arguments do gesture towards a progressive new praxis of reading in Creative Writing pedagogy, neither writer attempts to model what form this reading practice might take.

But a model has been proposed by Marcelle Freiman in her article, 'Writing/Reading: Renegotiating criticism' (2005). She sees, in the poststructuralist notion that the reader writes the text while reading, a corollary, that 'the writer "reads" the text in writing it', and argues that by introducing theory and its assumptions into the reading / writing nexus it is possible to transfigure the notion of 'reading as a writer'. Her argument is that, by viewing creative writing through a poststructuralist lens, it is possible to enable 'writers to describe what they have always known - that reading and writing are intrinsically connected and inseparable' (Freiman 2005). With reference to the reading that occurs in the act of composition, she advances a notion of reading and writing as a single kinetic activity,
a backwards-and-forwards movement of construction and reconstruction; a dynamic conversation that occurs unseen and with great rapidity in a conceptual space somewhere between the remembered reading of other exemplary texts and the writing of new ones. (Freiman 2005)

Freiman models her 'reading in writing' praxis by deploying Roland Barthes' notions of lisible (readerly) and scriptible (writerly) modes of reading. Barthes' readerly mode consists of reading a text passively, for the meanings codified in it; his writerly mode, of reading in a ludic way, playfully interrogating the text as a repository of a myriad of meanings. Freiman inflects these categories towards writing. In Freiman's model the writerly is involved in the production of the original formless creative outpouring, which the writer him- or herself then reads in a readerlymode, making editorial choices that defer to the desire to make meaning, Barthes' 'love-me':

So reading is a dialectical tension between desire and control. In the writerly function of reading, when we read we also construct meaning; we make choices about how we do this, 
based on grammatical and other textual structures, and references to familiar codes - we constantly "make" the reading into something we can relate to our understanding. (Freiman 2005)

\section{Pleasure balks, bliss appears}

Though Freiman's model is potent, suggests many lines of enquiry, and constitutes an important attempt to introduce critical theory into Creative Writing reading praxis, to a degree it falls back upon the old mode of 'reading as a writer'. Despite its promise to unite reading and writing in one practice, they remain separate; two forces in a dialectical interrelation. At the core of the model remains the notion that a writer's reading is deployed in the act of composition to impart aesthetic unity. The main difficulty with Freiman's model is that it reaffirms a reading / writing binary in which reading is the privileged term, possessing a hegemonic limiting force. Writing is weakened; made the product of intuition and chance. Though Freiman does acknowledge that a writerly reading of a text can subvert the structures imposed upon it by the writer - that prescriptively directing interpretations of his or her text is beyond the writer - she does not see this as empowering in and of itself, but empowering only because it forces him or her to read his or her own work with additional care in the readerly mode, to assert, more scrupulously, the historically conditioned codes by which meaning is made: 'Knowing that we can't control the reading allows us to write as skilfully and playfully as possible to present our meanings' (Freiman 2005). Freiman's model also elides the fact Barthes privileges the category of the writerly. In $S / Z$ he asks: 'Why is the writerly our value? Because the goal of literary work (of literature as work) is to make the reader no longer a consumer, but a producer of the text' (Barthes 1974: 4).

It is true that, in $S / Z$, Barthes sees the writerly as impossible, subsumed by the requirement to make meaning:

[W]here can we find [writerly texts]? Certainly not in reading (or at least very rarely: by accident, fleetingly, obliquely in certain limit-works): the writerly text is not a thing, we would have a hard time finding it in the bookstore. (Barthes 1974: 45)

But, as Terence Hawkes notes about Barthes, the readerly and writerly modes of reading are encouraged by different texts, and some works of literature can be said to approach the writerly ideal. These writerly texts, Hawkes argues, can have radical effects on their readers:

Where readerly texts (usually classics) are static, virtually 'read themselves' and thus perpetuate an 'established' view of reality and an 'establishment' scheme of values, frozen in time, yet serving still as an out-of-date model for our world, writerly texts require us to look at the nature of language itself, not through it at a preordained 'real world'. They thus involve us in the dangerous, exhilarating activity of creating our world now, together with the author, as we go along. (Hawkes 2003: 92-92)

In The Pleasure of the Text (1973), Barthes explicitly colours the categories of the readerly and writerly text with desire, the former becoming texts of plaisir, pleasure, the latter texts, of jouissance, bliss: 
Text of pleasure: ... the text that comes from culture and does not break with it, is linked to a comfortable practice of reading. Text of bliss: ... the text that discomforts ... unsettles the reader's historical, cultural, psychological assumptions. (Barthes 1990: 14)

Barthes's bliss can be engendered by privileging writing in reading, 'once the work is perceived in terms of a writing, pleasure balks, bliss appears' (Barthes 1990: 37).

Kenneth Patchen's narrator, Albion Moonlight, gives us a version of this statement inflected towards writing: 'Literature is what you write when you think you should be saying something. Writing begins when you'd rather be doing anything else: and you've just done it' (Patchen 1961: 18).

This quotation also intimates that fugue, absence from self, is involved in radical composition. Andrew Cowan addresses precisely this issue from a perspective that, though theory-literate, is nevertheless hostile to the introduction of theory into the Creative Writing classroom. With reference to Dawson's argument, he claims that 'thinking' or attempting to model a work's dialogism at the moment of composition misses the point - that it is those things the writer is unaware of putting into his or work it that might be the most meaningful aspect of it:

Inescapably, even axiomatically, the literary work will express the clash of living discourses in society, regardless of an author's conscious intentions, and to privilege or advocate the conscious 'orchestration' of that clash in accordance with the values of an 'oppositional politics' may be to miss the extent to which a literary work's unconscious disclosure of ideological assumptions is precisely what will make that work valuable or significant to subsequent readers. (Cowan 2011)

His argument emphasises the importance of 'blind spots', or not-knowing, in the Creative Writing setting. What Cowan does not acknowledge is the extent to which his thesis is indebted to theory, or the fact that Barthes' theory, which allows writing to be thought of as a process which contains moments of orgasmic absence from self, or Delueze's notion of radical writing as a 'delirium that carries [language] off', can both respect the fugues that occur periodically when writing, but also enable their connection to broader cultural discourses in a potent way (Deleuze 1997: 5). The flexibility of theory, or rather, ludic poststructuralist theory (the reason for this specific distinction will be made clear) is such that it can discuss Cowan's blind spots, without codifying them - indeed it is central to the whole project of such theories that they do not fix meanings. It is not clear why Cowan sees understanding theoretically the value of a flight from meaning and an authorising position as inimical to pursuing such a flight.

\section{Calls for the theorisation of Creative Writing}

I have argued that the practice of 'reading as a writer' creates a binary opposition, in which reading and writing are seen as separate, and leads to the production of texts that acquiesce to and perpetuate, rather than disrupt, conventional cultural codes. This is not a new notion. It was first proposed in 1988, from a Marxist theoretical perspective hostile to Creative Writing, in Mas'ud Zavarzadeh and Donald Morton's 'The Cultural Politics of the Fiction Workshop'. This essay offers a searing critique of the US Creative Writing 
workshop pedagogy of the late 1980s, early 1990s, indicting an alliance between creative writers, deconstructionists, and traditional humanists in the US academy for affirming the power structures of (late) Capitalism, in part, by conceiving of the practices of reading and writing as distinct, legitimating a perspective in which, ' $[\mathrm{t}]$ he writer is always the creative producer whereas the reader is the passive consumer' (Zavarzadeh \& Morton 1994: 87). For Zavarzadeh and Morton, ' $[\mathrm{t}]$ he political value of such a theory of reading for the dominant class is that in the name of "reading" the reader is taught how to "obey" the writer, who stands for authority and controls meaning' (Zavarzadeh \& Morton 1994: 87). They see the division as arbitrary: 'reading is nothing less than a rewriting, and all writing is a reading' and call for the introduction of radical critical theory into the Creative Writing classroom to interrogate its assumptions (1994: 87). Overall Zavarzadeh and Morton's critique is not sound, there are major problems with it. They do not acknowledge, or predict, that the introduction of radical theory into the setting could come from within Creative Writing departments, that Creative Writing itself could become a site of contestation. Also, there seems to be little evidence of the coalition between Creative Writing and traditional humanities departments they condemn: the hostility of literary departments towards Creative Writing would seem to persist - Morley notes that Creative Writing academics still must 'justify their work as some pedagogical adjunct to literary studies or social work' (Morley 2007: 252); while many writers in the Academy remain resistant to theory, as Michelene Wandor writes, in her The Author is Not Dead, Merely Somewhere Else (2008), despite the fact that literary theory's 'contentious questioning of what constituted a "literary" text, and its focus on process, through the development of linguistics' enabled Creative Writing pedagogy to be thought of as possible, "on the whole, CW spurns theory, or opposes its "practice" (right-brain) to theory's intellectualism (left-brain)' (Wandor 2008: 84, also see Cowan 2011 and Harris 2008). Moreover, it would seem that it is precisely through an alliance with other humanities departments that theory could be introduced into the Creative Writing setting - where else could the impetus come from?

I would also take issue with the claim of Zavarzadeh and Morton's piece that the later, more playful and literary works of the poststructuralists lack contestational potential:

[A]s the work of these (post)modern philosophers (in response to the historical situation in the West) moves away from rigorous conceptual analysis and dissolves into a ludic, anticonceptual 'literariness,' their effectivity for the critique of the cultural politics of late capitalism rapidly diminishes.

(Zavarzadeh \& Morton 1994: 85)

It is their argument that: 'Only a radical Marxist critique of these institutions [the regime of capital and its knowledge industry] can lead to a revolutionary rather than reformist, conclusion' (Zavarzadeh \& Morton 1994: 89). However, some ludic theories could be positioned as radically contestational; in fact, they are better equipped to describe the myriad of contingent realities that have replaced a univocal truth - and to challenge the monolithic core of postCapitalist epistemology that both resists an interpretation of the world as polysemous, and dissembles a false polysemy - than a strict Marxist position, which attempts to impose its own totality. As examples, I would point to the late writings on literature of Gilles Deleuze, collected Essays Clinical and Critical (1993), or the works of Jean Baudrillard which playfully fuse Marxist critical theory with cultural theory tropes to produce a penetrating critique of late Capitalism (see Baudrillard 1994). An alignment of creative writing and ludic theory would be more likely to produce experimental texts of the kind 
Zavarzadeh and Morton call for: 'subversive texts ... innovative writing [that] intervenes in the discursive practices of culture and demonstrates that what is offered as natural / unchangeable / real is in fact an "unnatural" construct that can be changed' (Zavarzadeh \& Morton 1994: 100). Indeed, the writing that Deleuze valorises in his Essays Clinical and Critical is writing that achieves this subversion: literature that (in his ludic and literary formulation)

opens up a kind of foreign language with language, which is neither another language nor a rediscovered patois, but a becoming-other of language, a minorization of this major language, a delirium that carries it off, a witch's line that escapes the dominant system. (Deleuze 1997: 5)

Perhaps Zavarzadeh and Morton's dismissal of literary, playful theoretical positions comes from the fact that for them, from their Marxist position, revolution is progression towards egalitarian order, and ultimately stasis, while these theories are anti-teleological and proceed via ceaseless 'becomings' (to employ Deleuze's concept).

In The Author is Not Dead, Merely Somewhere Else, Wandor advances a critique of the Creative Writing workshop that has many points of similarity with Zavarzadeh and Morton's, except that it proceeds from an internal and sympathetic perspective. She argues the pedagogy pursues two separate paths, one Romantic, the other therapeutic, both visions that see creative writing as expressions of an element of the writers' selves - on the one hand their original genius, on their other their unique experiences - perspectives that are irreconcilable and cannot be contained within the same pedagogic model: 'The first overvalues the art, the second overvalues the person, and together they confuse the object of the work and its objectives' (Wandor 2008: 128). But since both approaches focus on the product, as it reflects the individual who has created it, rather than the process, they give rise to 'a pedagogic practice which renders the workshop as a House of Correction, built round re-writing, rather than writing' (Wandor 2008: 131). Therefore,

$[\mathrm{u}]$ ntheorised (or, at best very under-theorised) principles of 'criticism' are translated into by turns brutal and patronising exchanges [which] denies CW's relationship to its own histories, which are those embedded in the history of English: literature, literary criticism and literary theory. (Wandor 2008: 131)

Like Zavarzadeh and Morton, Wandor sees the state of affairs she deplores as in part arising from the particular practices of reading and writing emphasised by the pedagogy of Creative Writing. For her, the practice of 'reading as a writer' leads to a focus on the writer, and therefore the product not the process: 'To build a pedagogical set of principles on "reading" the impossible, the invisible [authorial decisions in the act of composition], is to reaffirm the unteachability of the most highly desired and elusive element of CW: talent, and genius' (Wandor 2008: 147). This problem, for her, arises from the importation, without reinflection of formalist literary theory into the Creative Writing setting:

[T] he judgement of product (the complete text) prematurely forecloses the pedagogic process, leaving no time or space for the investigation and understanding of its 'raw' materials language, conventions, and, in the end, the nature of the individual, socially contexted, imagination. (Wandor 2008: 148) 
The solution Wandor proposes consists of emphasising the importance of unconscious decisions to the act of composition, and of seeing reading and writing as separate practices: 'even while links between reading / study and the writing / production of literature are made, they must also, conceptually and practically be separated' (2008: 184). The denial of the authorial intention frees Creative Writing pedagogy from a focus on the self of the writer, and the separation of reading and writing into two distinct activities moves the pedagogical focus from the rewriting (reading) of completed student work, to the distinct activities of engaging with existing literature and of composing new work.

[A]ny CW study is seriously incomplete ... unless it is a series of writerly and productive studies which develop verbal acuity and a writerly understanding and practice of discursive and imaginative writing, alongside the readerly-based studies of literature (however categorically defined) which are already in place, thus effecting a rapprochement between them all.

(Wandor 2008: 230)

For Wandor, then, humanist literary theory (her concluding manifesto is a homage to a passage in Terry Eagleton's Literary Theory (1983), a thinker Zavarzadeh and Morton single out for particular execration) offers a way to remodel Creative Writing pedagogy, to open it up to the dialogic currents of ideology, culture, history (it is ironic that Wandor specifically critiques Dawson for emphasising a theory of reading). But, despite her call for a move away from a focus on the self of the writer, her humanism puts individual writers and readers (as subjects of her 'writerly and productive studies' and 'readerlybased' studies of literature') back at the centre of Creative Writing teaching. The move away from workshop pedagogies focussed on the self, and the 'rapprochement' she desires could be better effected by attempts to understand the moment of self-negation that occurs in composition and by developing a theoretical model that can understand reading and writing as one fluid practice, not distinct activities. Ludic theory offers a way to do both of these things. At one point, Wandor repudiates one of the founding ideas of poststructuralism, the idea that thinkers (and she is writing specifically of Barthes' notion of the death of the author) have 'appropriated the term "writing" as a metaphor for reading, and consequent critical exegesis / interpretation', in order to move away from a state of affairs in which authors had authority over the interpretation of their texts (Wandor 2008: 163). For her, the idea that such control required challenging is 'one of the most ridiculously manipulative ideas in the literary postmodern lexicon': 'How on earth can any author / writer "control" the reading and/or meaning of their text?' (Wandor 2008: 164). But the theorists she critiques are not claiming that a specific individual human author has control of the meanings of their texts, but that the function of authorship in general, and the ideological codes that are embedded in it exert this kind of control. The notion of the death of the author and poststructuralism more generally offer ways of interrogating certain codes that have been naturalised in the Western tradition, of showing them to be conventions, and, therefore, of opening up literature to a plurality of cultural meanings, just as Wandor wishes to do. They also model the critical and active reading implicit in Wandor's call for dialogism, and, in seeing reading as an act of writing, offer a view of composition as a process that can never be concluded and of reading as a creative activity in its own right, bound up with writing in one fluid praxis.

Another writer who calls for a theorisation of Creative Writing as a discipline is Mike Harris in his 'Are Writers Really There When They're Writing About Their Writing?' (2008). His position is hostile to the introduction of what he terms 'reader-and-text' theories, by which he implies humanist literary theory, 
sociological poetics, and more ludic critical theory positions. The article is an attack on what he views as external theoretical impositions and a call for new understandings to emerge from within the discipline: 'So, if we want theories that do fit, I fear we may have to invent our own' (Harris 2008). Harris's repudiation of theory relies on two key notions. The first is drawn from conventional discourses about 'reading as a writer' - that the ways writers read differs from the ways in which students of literature, or other readers read: 'when we read other fictional works as writers, we read them as de facto instruction manuals for technique, style, structure and thematic possibility' (Harris 2008). Harris gives the reader examples of his writerly insight, contrasting them with the 'static' interpretations of literary scholars who 'mistake effects for causes'. This restates the conventional idea that literary scholars read a product, writers a process; for Harris 'reader-and-text' theories are 'incomplete because they fetishize the finished text' (Harris 2008). This is a claim without much justification: the readings of formalists posit texts as part of a ongoing cultural process that works to produce new combinations of textual elements; structuralists see reading as a dynamic activity that activates the meanings embedded in the language of a text, meanings that are not fixed, but mutable, the text the langue, the individual reading the parole; while poststructuralist readings explicitly posit all readings as process. Moreover, it is not clear what constitutes the writerly insight - the actual readings Harris offers could easily have emanated from a literary theory perspective. Harris's second attack on theory is based on a model of composition that is tripartite, with the elements held in different balances in the processes of different writers. It begins with the unconscious birth of an idea, proceeds through its largely unconscious development, and concludes with its conscious shaping, which is the point at which writers deploy their special mode of reading. Harris's view of composition, therefore, relies both on arbitrarily dividing up the act of composition and on claiming a unique mode of reading for writers. Further, it is his implicit claim that theory lacks the tools to articulate anything useful about the unconscious part of the composition process, which would not appear to be true.

\section{Desire machines}

Many of the models of composition this essay has explored posit composition as a divided performance - separated into writing (unconscious) and reading (conscious) and claim a spurious special status for the readings of writers. It is the argument of this essay that lucid theory can offer a means of modelling composition as a fluid performance which does not require 'reading as a writer' to be seen as distinct from mere reading. Therefore, it could offer a way to reformulate reading practices in the Creative Writing classroom. Harris describes using theory to explain aspects of the creative writing process as reaching for 'ill-fitting off-the-peg formulations', but all disciplines reach out to other modes and ways of thinking for various purposes (Harris 2008). Theory (and more broadly philosophy) offers ways of conceptualising the world, practices, and so forth, so it is natural to turn to it to conceptualise the practice of creative writing. Moreover, creative writers, of all academics, should feel least fettered by theory, best placed to use such ideas imaginatively to productive ends. The great value of antic poststructural positions for Creative Writing is that engagement with these kinds of ideas encourages the writing of fictions that can offer an epistemological challenge, attack conventional ways of seeing the world, without being tethered to any doctrinaire ideological position. 
Angela Carter's The Infernal Desire Machines of Doctor Hoffman (1972) is a novel which both depicts and enacts an attack on Enlightenment

epistemologies. The home city of the protagonist, which, before being harried by Hoffman's desire machines, was 'solid, drab', 'throve on business', 'was prosperous' and ' thickly, obtusely masculine', becomes plagued by antic transformations: 'Those bluff, complaisant avenues and piazzas were suddenly as fertile in metamorphoses as a magic forest' (Carter 2010: 10, 12). The stolid edifices of bourgeois capitalism are detonated: 'the Cathedral expired in a blaze of melodious fireworks' (Carter 2010: 26). The assault is capricious, oneiric: 'Hardly anything remained the same for more than one second and the city was no longer the conscious production of humanity; it had become the arbitrary realm of dream', and the city, though it becomes violent and terrible, also waxes beautiful, 'roses ... clambered everywhere and dripped as if perspiring the heaviest, most intoxicating perfume, which seemed to make the very masonry drunk' (Carter 2010: 13, 26). The desire machines' potency is derived from a ludic version of poststructuralist thinking; Dr Hoffman's Phenomenal Dynamics is described by one character as being founded upon the following three assumptions:

"The universe has no fixed substratum of fixed substances and its only reality lies in its phenomena ... only change is invariable ... the difference between a symbol and an object is quantitative, not qualitative." (Carter 2010: 109-110)

Ultimately desire proves more potent than Hoffman's pseudo-scientific principles and the machines he devises to unleash and control it: 'I knew from my own experience that, once liberated, those desires it seemed to me he cheapened as he talked of them were far greater than their liberator and could shine more brightly than a thousand suns' (Carter 2010: 254). The novel's protagonist Desiderio, partly out of an instinctual fear of desire unleashed, kills Hoffman, and the novel's true locus of desire, Hoffman's daughter Albertina, and destroys the machines. The world then reverts to routine: 'because of what I did, everybody is relatively contented, because they do not know how to name their desires so the desires do not exist' (Carter 2010: 247-248). But Desiderio is left suffering regret, 'that insatiable regret with which we acknowledge that the impossible is, per se, impossible', and it is intimated that while desire on Hoffman's militaristic male model failed to be radically transformative, desire on female principles, represented by Albertina, might have been (Carter 2010: 264). The Infernal Desire Machines of Doctor Hoffmann is a text which 'takes apart the "machines" of love, of narrative, of social structure', to reconstitute them in novel formulations, a text which fuses a dazzling array of genres into a mischievous and beautiful whole, and which operates as an exemplary critique of bourgeois patriarchy and capitalism (Smith 2010: viii). It is a novel that hints at the power of an experimental fiction whose motive engine is eros, and atomises and condemns the forces by which that eroticism is either quelled, or harnessed in the service of misguided ideals. It is a book that teaches its readers to read the texts of culture differently, critically, a transformation which could feed back into acts of writing. What is required by Creative Writing as a discipline is a means of making such radical reading practices an explicit part of its pedagogy; Freiman's model of 'reading as a writer' as a unified theory and praxis, incorporating a theoretical perspective and linked by the desire that activates them both, needs to be inflected towards bliss, thereby generating a radical reading praxis, a praxis I shall term, 'writerly reading'. 
But what is this 'writerly reading'? Another writer who calls for a new dynamic reading practice in Creative Writing is Neil McCaw in his essay 'Close Reading, Writing and Culture' (2011). He challenges the prevailing model of reading as writer, arguing that it leads to 'the triumph of practicebased close reading over all other forms of textual interpretation ... a functionalist caricature of reading as a process [that] fundamentally lacks imagination and creativity' (McCaw 2011: 27). He calls for an 'enlightened close reading [that] facilitates a broader sense of writerly and intellectual development, in which the words on the page are but the first step in a wider cultural interaction' (McCaw 2011: 32). He sees the 'desired outcome' that students 'repeatedly consider the interactions between what they write and issues of human identity, meaning and communication' (McCaw 2011: 32, 33). This, I believe, would constitute a radical and progressive reading practice. McCaw, though, does not fully set out his strategy, nor does he discuss how such a reading strategy might impact upon composition, reading while writing. I will attempt here, to find a way of doing both these things, and, responding to McCaw's implicit challenge to employ imagination and creativity to seek a solution to the problem of 'reading as a writer', will propose a model based on a playful use of theory.

The possibility of mapping the categories of the readerly and writerly onto Michel de Certeau's division of practices into strategies and tactics, discussed in his work The Practice of Everyday Life (1980), is suggestive. De Certeau's conception is a challenge to instrumentalist models. He sees society as an ideological space divided into 'producers', the hegemonic institutions and structures of power, and 'consumers', the individuals who make up a society. Strategies are the practices of the elite, designed to elicit certain responses, while tactics are the practices of individuals that, while influenced by strategies, to an extent overflow, escape determination. This in turn maps on to a binary in which written texts are part of a hegemonic strategy, and the actual readings of individuals are tactics that refuse to conform to the prescribed reading the text expects; readers, in de Certeau's formulation, 'are travellers ... poaching their way across fields they did not write' (Certeau 1988: 174). Therefore reading enables the creation of a place where the reader can both escape hegemonic strategies and resist them:

$[\mathrm{T}] \mathrm{o}$ read is to be elsewhere, where they are not, in another world; it is to constitute a secret scene, a place one can enter and leave when one wishes; to create dark corners into which no one can see within an existence subjected to technocratic transparency and that implacable light that ... materializes the hell of social alienation. (Certeau 1988: 173)

The value of such a vision of reading in delineating a praxis of 'writerly reading' is clear. If inflected back to writing, it allows for the creation of texts that promote writerly modes of reading, texts whose writers, while reading texts, the world, and, most crucially, while engaging in the fluid, combined act of reading and writing that occurs during composition, exercise a kind of destabilising reading. This allows reading in writing to be modelled as a loss of control or power, a denial of an authorising position, or proper place from which to write, rather than a controlling function.

In order to model a 'writerly reading', I will turn to the figure of the bachelor, or celibatory machine, in particular the vision of it de Certeau advances in his essay, 'The Arts of Dying' (1975).

The figure is first identified in the work of Michel Carrouges and takes its name from the full title of Marchel Duchamp's Large Glass (1923), La mariée 
mise à nu par ses célibataires, même (The Bride Stripped Bare by Her

Bachelors, Even). Carrouges sees bachelor machines in the works of radical artists and writers of the early twentieth century, the most celebrated of which is the torture machine in Franz Kafka's 'In der Strafkolonie' ('In the Penal Colony') (1919). For Carrouges, '[a] bachelor machine is a fantastic image that transforms love into a technique of death' (Carrouges 1975: 21). They are 'first and foremost mental machines the imaginary work of which suffices to procure a real movement of the mind' (Carrouges 1975: 44).

De Certeau extends the definition of the celibatory machine to include texts, discursive spaces themselves. Celibatory machines for de Certeau are texts which challenge 'the principle of Occidental ambition'. They do this through a blasphemous and derisive 'baring of the scriptural myth' (Certeau 1986: 158). Hegemonic writing

...was the action / myth of a society capable of transforming itself into a blank page upon which it could write the story of its own genesis, and relate that story to what the society was separating from (as knowledge) without losing the referent (since it used it). A machine par excellence, in turn pedagogical, entrepreneurial, urbanist, scientific, and revolutionary. (Certeau 1986: 158)

The celibatory machine, with 'its traps and machinations ... undermines the simulacrum of being that comprised the [biblically derived, bourgeois] gospel of the domination of things by the letter and the cipher' (Certeau 1986: 158). It does this by inverting the utility of the text, becoming a game, a 'fable: without power' (Certeau 1986: 163). It is of the type of Barthes' writerly text.

The celibatory machine is supposed to be inutile: 'Despite the ironic, meticulously outlined directions for use that accompany it to detail its functioning, the represented machine is not intended to work' (Certeau 1986: 165). Yet somehow 'it has the strange power of rearranging the practices of he who merely reads it; it alters our way of transforming texts by reading them' (Certeau 1986: 165). It does this by staging a mocking reversal of the mechanisms by which hegemonic institutions compel affiliation. These institutions exact belief as the price of the disclosure of profound, esoteric knowledge. The celibatory machine, by contrast, places everything outside itself, hides nothing, authorises nothing, does not require the reader to believe in anything. '[T]he apparatus shines like a blade. It has the cleanliness of a suicide which makes way for the world's alterity, with no compensation' (Certeau 1986: 166).

Therefore, the celibatory machine functions by excluding the object of its desire, suppressing the 'love-me' the writer has for his or her reader: 'Its engine is this "other" repressed with so much precision - and therefore, first and foremost, the reader' (Certeau 1986: 167). Eroticism sets it in motion but its 'eroticisms are directed toward a (something) other which will never be here', an 'eroticism which increases with its loss of power (religious, cosmological, or political) over the other' (Certeau 1986: 157, 167).

Since the celibatory machine creates its energies by repressing the desire for a reader that is in all writing, forcing it to return transfigured, a more powerful eroticism, it can transform reading practices; excluded, the reader understands his or her alterity with respect to the text, but, at the same time, since the text relinquishes its authority, is made to recognise his or her power over it. The celibatory machine's excluded desire can refer to the reader as other, or can be explicitly narcissistic, can pertain to the desire the writer has for him- or herself 
as a reader, an excluded other, of his or her own text. The machine's engine is a vacillation between inside and outside, between same and other, between desire and repression, a back-and-forth motion which resembles both the oscillation between text and contextual web in the act of reading another's work, and the flickering between writing and reading one's own writing, that occurs during composition.

The 'writerly reading' praxis suggested by the figure of the celibatory machine would be a radical dislocation, a praxis which, when practiced by a reader, either of other texts, or of his or her own in the act of writing (these being the same praxis), would lead to a recognition that the power he or she has to disrupt and disperse a text's meanings can be a function of the text's disavowal of authority, of its inversion of the conventional hierarchy of writing and reading. It would force readers to recognise their otherness with respect to the texts they read, their own and those of others, be wary of the sleight of hand by which readerly texts promote belonging, engagement. It would restore vigour to the text, without diminishing the ludic force of reading, and enable culture, ideology, and affect to flood back in; readers, seeing themselves as aliens poaching their way across the text, will no longer believe its claims, but interrogate them, read 'politically'.

It is important at this juncture to distinguish this line of argument from what Dorothy Hale calls 'the aesthetics of alterity' (Hale 2009a, 2009b). The aesthetics of alterity, Hale claims, unites modernist and postmodernist writers, and twentieth-century defenders of the ethical value of literature from both preBarthesian formalist and radical poststructuralist traditions. It consists of a claim that

the art of the novel is found in the genre's inherent capacity for otherness, a capacity that comes to life when author and reader participate in a circuit of interanimation, retaining their own subjective particularity even while they are united in their contact with a commonly shared and uncircumscribed spirit (divine or human) that is the basis for their relation. (Hale 2009b: 13)

This line of thinking claims novels possess the capacity to encourage their readers to see the world through the eyes of an other, something that has a moral and ideological function:

Our experience of how literature binds us (binds us to characters, binds us to its emotional effects) is thus the happy psychological condition that frees us from our usual epistemological limits... And this felt recognition of the limits of our ways of knowing opens up ... the possibility that we might change for the better, that we might actively try to judge less and undergo more. (Hale 2009a: 901)

The ethical energy of the aesthetics of alterity arises when the gap between the same and the other, between the reader and the alterior represented in fiction, is closed. The force that achieves this fusion is 'love': 'Love enables the self to see the other and honor her difference' (Hale, paraphrasing Salman Rushdie, 2009b: 15). Even some radical and fantastical fictions, which openly display the 'irreducible relationality between truth and fiction', cultivate alterity as a means by which the reader can know the other, as Hale points out in a discussion of Laura Riding Jackson's aesthetic stance (Hale 2009b: 17). Hale correctly identifies that this profoundly humanist vision of the novel's moral 
function is one that holds sway in current Creative Writing pedagogical methods:

To show and not tell, to write what you know - such creativewriting-workshop dicta are connected to a conception of the novel as a social discourse different from other social discourses, made different by the aesthetic effects and ethical dilemmas particular to it. (Hale 2009a: 904)

It is therefore important to challenge this conception of the value of fiction, if Creative Writing as a discipline is going to move towards polysemy, and away from a pedagogic methodology with a very narrow conception of what longform prose fiction can be.

In the model of 'writerly reading' developed here from de Certeau's work on celibate machines, there can be no love, no humanist paradoxical identification with the other, the other remains implacably other. The energy of a 'writerly reading' perspective increases with the loss of power over the desired other, the other can never be known, grasped, and therefore (and this is the mendacity of the aesthetics of alterity) made safe, same, brought within the boundaries of the known through love. There is only an unrequited eroticism. The desired bride remains separated from the bachelors by an impermeable barrier; if the observer (reader) were to take the place of the victim (other) beneath the harrow of the penal colony's torture machine there would be 'no sign of the promised redemption' (Certeau 1986: 163). This is crucial, for the energetic wavering of the text, given rise to by the 'writerly reading' praxis argued for here, relies on the fact that, immanent within it, are both the desire for the other, for a reader, and the impossibility of consummation or identification with that other. Desire must, therefore, be repressed in order for it to become possible to write.

Finally, an aside. The flickering at the heart of a 'writerly reading' praxis recalls Foucault's depiction of transgression in 'A Preface to Transgression' (1963): transgression 'incessantly crosses and recrosses a line which closes up behind it in a wave of extremely short duration, and thus it is made to return once more right to the horizon of the uncrossable' (Foucault 1977: 34). And to transgress might be crucial if writing is to escape its limits: 'Transgression opens onto a scintillating and constantly affirmed world, a world without shadow or twilight, without that serpentine "no" that bites into fruits and lodges their contradictions at their core' (Foucault 1977: 37).

\section{Practical pedagogy}

This essay could be accused of confusing the debate, of merely adding another theoretical perspective, de Certeau's, to the theories mobilised by other writers on the same topic, including, as demonstrated, Bakhtinian dialogism, Barthesian poststructuralism, and Althusserian critical theory. I would defend my choice of de Certeau because his heterological thinking, his science of alterity, seems ideal for addressing that which was lacking in the debate - an account of the position of the other to whom all acts of writing appeal (who, in composition is both same, the writer, and other, the writer as reader of his own text). But, in order to retain any ground it has gained, this essay must conclude with practical suggestions of pedagogical methods by which a 'writerly reading' praxis might be encouraged in the creative writing classroom. There are three key things to address. First, what texts should students be encouraged to read, and how should they be encouraged to read them? Second, what 
exercises should be used to promote a 'writerly reading' in the act of composition? And third, how should students critique the texts of peers when 'workshopping'? I will deal with each in turn.

I opened this essay by claiming there is a need to liberate reading in Creative Writing pedagogic methodology, and this I think is crucial. Students should read broadly, all kinds of texts. Further, they should do so without distinguishing between them. A key advantage of such an 'egalitarian' omnivorous reading practice would be to make Creative Writing a crucible in which thought from all disciplines is combined. Hopefully this essay has provided some examples of this practice in the way in which it has used theoretical texts playfully, not as methodology but exemplary works of the imagination, and engaged with fictions seriously, interrogating them for the things they articulate about writing. The two novels I have referred to in this essay, The Journal of Albion Moonlight and The Infernal Desire Machines of Doctor Hoffman, do, admittedly, come from particular experimental traditions, the former high-modernist, the latter playfully postmodernist, but the reading to be encouraged in Creative Writing students should make no distinction between texts, on the basis of aesthetic merit or any other criteria. Indeed, one of the problems with the Barthes' and de Certeau's engagements with literature could be seen as the problem of the avant-garde - in order to give force to their arguments they choose certain exemplary texts, despite the fact their theses emphasise the fact that certain kinds of reading practices can transmute any text. In fact, it could be argued, as Jacques Rancière has done, there is no such thing as a radical or conservative art work per se:

The arts only ever lend to projects of domination or emancipation what they are able to lend to them, that is to say, quite simply, what they have in common with them: bodily positions and movements, functions of speech, the parcelling out of the visible and the invisible. Furthermore, the autonomy they can enjoy or the subversion they can claim credit for rest on the same foundation. (Rancière 2004: 19)

So the project should be to encourage a subversive reading of all texts, a reading that recognises the utter alterity of texts, a reading not for meaning, nor for technique, and certainly not for identification, but a reading attuned to the strangeness of textual affect. I would argue, though, along with de Certeau, that some works can teach readers, heuristically, this kind of dislocation, a dislocation that they can take into other texts, though unlike de Certeau, I would argue that these works are not confined to any particular historical period, nor school of literary production. Therefore a program of reading for Creative Writing courses might include such exemplary works as, for example: The Journal of Albion Moonlight; The Infernal Desire Machines of Doctor Hoffman; William Burroughs's disturbing corpus; Lorrie Moore's short stories, which perform an uncomfortable détournement of American 'dirty realism'; Ali Smith's exuberant works of postmodern écriture féminine; Robert Coover's ludic narratives; Kelly Link's twisted contemporary fairy tales; Charles Robert Maturin's uncanny late Gothic novel, Melmoth the Wanderer; the iconoclastic work of Raymond Roussell; M John Harrison's hollowings out of the often consolatory genres of fantasy and science fiction; and the comic and collective writings of Daniil Kharms; to name a few idiosyncratic choices.

The value of the celibatory machine model for conceptualising the act of composition is that it allows us to think the blissful fugue of 'inspiration' without resorting to an arbitrary division between writing and reading (praxis and theory); at the moment of writing, the writer, instantaneously his or her own reader, becomes the desired but repressed other of his or her own 
eroticism. This explains the mysterious energy that drives the process; writers long for themselves, yet can never attain themselves. How practically, though, can students be encouraged to see composition as a fluid process of reading / writing, activated by a denied eroticism? It is key, I think, as Wandor argues, that the Creative Writing classroom is not solely a space for rewriting, the 'workshopping' of other students' work - though there is a move away from this pedagogy, it has proved tenacious. Students, at all levels, and of all 'abilities' should be encouraged to engage in writing exercises. Hazel Smith, in her The Writing Experiment (2005), offers an excellent repository of exercises and techniques that can be used to promote radical and playful writing. But any traditional creative writing exercise would suffice. What is crucial is a particular methodology, attitude, or inflection. It involves a kind of distancing, a keeping in mind the alienation of the writer from the text, and an emphasising of composition as a unified performance. For some, revising as they go may be the chosen method, for others a technique in which a period of writing is followed by rephrasing, shaping, and paring might be preferable, but in both instances it should be emphasised that the 'editing' is not a different kind of activity, 'left-brain' as opposed to 'right-brain', rational as opposed to creative, conscious as opposed to unconscious, 'symbolic' as opposed to 'imaginary' (in Lacanian terms), but simply 'more writing'. This move will not only be productive theoretically, but should help students to avoid producing conformist work - an emphasis on editing as a separate process can often lead to students amputating the strangest and, therefore, most affecting parts of their work; as Smith writes, '[t]he most interesting elements of a creative text are often irrational, the ones which stick out from the rest and which are tempting to cut away' (Smith 2005: 278). So taking, as an example, the classic exercise of writing a passage stimulated by a fragment of another text: students should be encouraged to write for a period of time, to produce something to read out to peers, which in no way conforms to students' ideas of what their peers expectations might be. The choice of the stimulus text might be important toochoosing an extract from a technical manual, or a political pamphlet, for instance, might help bring about the necessary alienation. In following a 'writerly reading' pedagogy, it would be important to inculcate an alienated stance in students towards their own productions, to emphasise a vision of writing as a continual process of transformation, and not to encourage them to cleave to their 'intuitions' (while at the same time emphasising the 'sanctity' of their idiosyncratic productions). It would also be important to encourage students to find ways to conceptualise the fugue state of inspiration - however idiosyncratic and playful - not to think of it as in some way ineffable. One example might be, taking inspiration from the writings of Carl Jung, to think of inspiration as a way of accessing a collective pool of oneiric imagery, but there are many others, and they need not be plausible, nor theorised.

When 'workshopping' pieces, it would be important to cultivate the correct attitude towards the writing under discussion. Students should read peers' work in the same way they are encouraged to read published texts, and discussions of work should steer clear of judgement focussed on the individual whose production it is, the manifest content of the work, traditionally writerly technique, or the fostering or erosion of engagement, and instead should concentrate on affect (cultural, ideological, etc) as it is present in the alien, yet vibrant, language of the text, discussing the strange things language can do as language, not as system of signs pointing the way to a 'real'. There should also be an awareness on the part of all involved, students and tutors, that, as Smith puts it, 'comments from other people may on occasion tend towards conformity rather than innovation' (Smith 2005: 278). Iconclasm should not be subsumed by group critique. 


\section{Conclusion}

It is crucial that Creative Writing as a discipline move towards a more radical, liberated reading praxis, a 'writerly reading'; this will help it transform from a place in which existing cultural codes are replicated and from which they are promulgated, to a space where the interrogation of cultural codes can take place and new, radical codes can be formed, a locus of dissent.

\section{Works cited}

Barthes, R 1974 S/Z (trans R Miller). New York: Hill \& Wang return to text

Barthes, R 1989 'On Reading', in The Rustle of Language (trans R Howard). Berkley and Los Angeles: University of California Press: $32-43$ return to text

Barthes, R 1990 The Pleasure of the Text (trans R Miller). Oxford: Basil Blackwell return to text

Baudrillard, J 1994 [1981] Simulacra and Simulation (trans S Glaser). Michigan: University of Michigan Press return to text

Besant, W 1902 The Art of Fiction. New York: Brentano's return to text

Brande, D 1961 Becoming a Writer. New York: Harcourt, Brace return to text

Brooks, C and R Penn Warren 1959 Understanding Fiction. New York: Appleton-CenturyCrofts return to text

Bunn, M 2011 'How to Read Like a Writer', in C Lowe and P Zemliansky (eds) Writing spaces: readings on writing, Volume 1. Anderson, SC: Parlor Press: 71-86 http://wac.colostate.edu/books/writingspaces2/bunn--how-to-read.pdf (accessed 8 June 2011) return to text

Carter, A 2010 (1972) The Infernal Desire Machines of Doctor Hoffman (intro A Smith). London: Penguin return to text

Cassill, R 1975 Writing Fiction. Englewood Cliffs, NJ: Prentice Hall return to text

Certeau, M de 1988 [1980] The Practice of Everyday Life (trans S Rendall). London:

University of California Press return to text

Certeau, M de 1986 [1975] 'The Arts of Dying: Celibatory Machines', in Heterologies: Discourse on the Other (trans B Massumi). Minneapolis: University of Minnesota Press: 156167 return to text

Cooley, N 2003 'Literary Legacies and Critical Transformations: Teaching Creative Writing in the Public Urban University', Pedagogy: Critical Approaches to Teaching Literature, Language, Composition, and Culture 3, 1 (Winter): 99-103 return to text

Cowan, A 2011 'Blind spots: what creative writing doesn't know', TEXT 15, 1

http://www.textjournal.com.au/april11/cowan.htm (accessed 6 August 2011) return to text

Dawson, P 2005 Creative Writing and the New Humanities. London: Routledge return to text

Deleuze, G 1997 'Literature and Life', in Essays Clinical and Critical (trans D Smith and M Greco). Minneapolis: University of Minnesota Press: 1-6 return to text

Eagleton, T 1989 [1983] Literary Theory: An Introduction. Oxford: Basil Blackwell return to text

Foucault, M 1977 [1963] 'A Preface to Transgression', in D Bouchard (ed) Language,

Counter-Memory, Practice: Selected Essays and Interviews (trans D Bouchard and S Simon).

Oxford: Basil Blackwell: 29-53 return to text 
Freiman, M 2005 'Writing / Reading: Renegotiating criticism' TEXT 9, 1

http://www.textjournal.com.au/april05/freiman.htm (accessed 30 May 2011) return to text

Friel, J 2004 'Reading as a writer', in J Newman, E Cusick \& A La Tourette (eds) The Writer's Workbook. London: Arnold: 13-18 return to text

Hale, D 2009a 'Aesthetics and the New Ethics: Theorizing the Novel in the Twenty-First Century', Publications of the Modern Language Association of America 124, 3 (May): 896-905 return to text

Hale, D 2009b 'The art of English fiction in the twentieth century', in R Caserio (ed) The Cambridge Companion to the Twentieth-Century English Novel. Cambridge: Cambridge University Press: 10-22 return to text

Harris, M 2008 ‘Are Writers Really There When They're Writing About Their Writing? ... And Can We Theorise About What They Say and Do?' The Creativity and Uncertainty Papers: the refereed proceedings of the 13th conference of the Australian Association of Writing Programs, 2008 http://www.aawp.org.au/files/Harris_2008.pdf (accessed 21 August 2011) return to text

Hawkes, T 2003 Structuralism and Semiotics. London: Routledge return to text

Lambert, G 2000 'On the Uses and Abuses of Literature for Life', in I Buchanan \& J Marks (eds) Deleuze and Literature. Edinburgh: Edinburgh University Press: 135-166

McCaw, N 2011 'Close Reading, Writing and Culture', New Writing 8, 1: 25-34 http://www.tandfonline.com/doi/abs/10.1080/14790726.2010.527349 (accessed 19 August 2011) return to text

Melrose, A 2007 'Reading and Righting: Carrying on the "Creative Writing Theory" Debate', New Writing 4, 2: 109-117 http://dx.doi.org/10.2167/new374.0 (accessed 30 May 2011) return to text

Morley, D 2007 The Cambridge Introduction to Creative Writing. Cambridge: Cambridge University Press return to text

Patchen, K 1961 [1941] The Journal of Albion Moonlight. New York: New Directions return to text

Rancière, J 2004 [2000] The Politics of Aesthetics (trans G Rockhill, with an afterword by S Žižek). London: Continuum return to text

Smith, A 2010 'Introduction', in A Carter The Infernal Desire Machines of Doctor Hoffman. London: Penguin: vii-xii return to text

Smith, H 2005 The Writing Experiment: Strategies for Innovative Creative Writing. Crows Nest: Allen \& Unwin return to text

Wandor, M 2008 The Author is Not Dead, Merely Somewhere Else: Creative Writing Reconceived. Basingstoke: Palgrave Macmillan return to text

Zavarzadeh, M \& D Morton, 1994 'The Cultural Politics of the Fiction Workshop', in Theory as Resistance. New York: The Guildford Press: 83-107 return to text

Tim Jarvis is a writer of both prose fiction and criticism, with particular interests in genre and radical fictions, and creative writing pedagogy. He recently gained a PhD in Creative Writing from Glasgow University, Scotland; his thesis was a work of contemporary Gothic with a metafictional element. 


\section{TEXT}

Vol 15 No 2 October 2011

http://www.textjournal.com.au

Editors: Nigel Krauth \& Kevin Brophy

Text@griffith.edu.au 